\title{
The Indigenous Prestice Black-Pied Pig Breed Differs from a Commercial Hybrid in Growth Intensity, Carcass Value and Meat Quality
}

\author{
Pavel Nevrkla ${ }^{1, *(\mathbb{D}}$, Eva Václavková ${ }^{2}$ and Miroslav Rozkot ${ }^{2}$ \\ 1 Department of Animal Breeding, Faculty of AgriSciences, Mendel University in Brno, Zemědělská 1, \\ 61300 Brno, Czech Republic \\ 2 Department of Pig Breeding, Institute of Animal Science, Prague-Uhříněves, Kostelec nad Orlicí, \\ Komenského 1239, 51741 Prague, Czech Republic; vaclavkova.eva@vuzv.cz (E.V.); \\ rozkot.miroslav@vuzv.cz (M.R.) \\ * Correspondence: pavel.nevrkla.uchhz@mendelu.cz; Tel.: +420-545-133-218
}

\section{check for} updates

Citation: Nevrkla, P.; Václavková, E.; Rozkot, M. The Indigenous Prestice Black-Pied Pig Breed Differs from a Commercial Hybrid in Growth Intensity, Carcass Value and Meat Quality. Agriculture 2021, 11, 331. https://doi.org/10.3390/ agriculture11040331

Academic Editors:

Agnieszka Ludwiczak and Javier Álvarez-Rodríguez

Received: 4 February 2021

Accepted: 6 April 2021

Published: 8 April 2021

Publisher's Note: MDPI stays neutral with regard to jurisdictional claims in published maps and institutional affiliations.

Copyright: (c) 2021 by the authors. Licensee MDPI, Basel, Switzerland. This article is an open access article distributed under the terms and conditions of the Creative Commons Attribution (CC BY) license (https:/ / creativecommons.org/licenses/by/ $4.0 /)$.

\begin{abstract}
The study was designed for the comparison of barrows and gilts of two contrasting genotypes in terms of growth ability, carcass value and meat quality. A total of 76 pigs (from $7 \pm 1 \mathrm{~kg}$ to $95 \pm 6 \mathrm{~kg}$ ) of the indigenous breed Prestice Black-Pied (PB) and the commercial hybrid of Large White $\times$ Landrace $\times$ Large White sireline $(\mathrm{CH})$ were included in this study. The groups were balanced regarding genotype and sex. Live weight at the age of 79 days $(p<0.001)$, live weight at slaughter $(p<0.01)$, average daily gain $(p<0.001)$, weight of carcass and left carcass side $(p<0.05)$ and ham proportion $(p<0.001)$ were higher in the $\mathrm{CH}$ group. The values of the given parameters were higher in barrows than in gilts. The effect of genotype and sex interaction was observed in lean meat content $(p<0.05)$ and backfat thickness $(p<0.01)$. The $\mathrm{CH}$ gilts showed the highest lean meat content and the lowest backfat thickness compared to the lowest values in the $\mathrm{PB}$ barrows. The value of $\mathrm{pH}_{45}$ $(p<0.01)$ and intramuscular fat content were higher in the PB group. The lightness $(p<0.001)$, yellowness $(p<0.01)$, drip loss $(p<0.05)$ and protein content were lower in the PB group. Higher values of lightness $(p<0.05)$, yellowness $(p<0.05)$ and cholesterol content $(p<0.05)$ were observed in the boars. Oxidative stability of the meat (malondialdehyde content) was more favorable in the PB pigs. The effect of genotype and sex interaction was confirmed for the $\mathrm{pH}_{24}$ value (the highest value was found in the PB barrows and the lowest in the $\mathrm{CH}$ barrows, $p<0.001$ ) and for the dry matter content (lowest in the PB gilts and highest in the $\mathrm{CH}$ barrows, $p<0.05$ ). Overall, the PB pigs were characterized by inferior growth and carcass parameters, however, with more favorable parameters for meat quality.
\end{abstract}

Keywords: local breed; three-breed hybrid; growth ability; carcass value; meat quality

\section{Introduction}

Local breeds represent an important biological source for the creation of new breeds or improvement of existing breeds, as well as for the protection of biodiversity and implementation of sustainable animal breeding [1]. At present, pig production and breeding is a highly specialized sector under high economic pressure. Breeding strategies and the selection of breeds reflect this trend. Commercial breeds, such as Large White, Landrace, Duroc and Pietrain and especially their hybrids in various combinations, cover a major share of the global market, while many local pig breeds may be near extinction. Such breeds can be characterized by special traits that lead to higher resistance to diseases and better meat quality [2]. It should be noted that the commercial production of pork meat results in high growth intensity, meat conformation and low fat content in meat, which may lead under some circumstances to a decrease in pork meat quality parameters, such as higher drip loss or deterioration in meat color and taste. However, the consumer trend 
is for meat of high quality and an acknowledgement of the importance of local breeds developed in certain regions. These breeds are linked to their local environment, and to some extent, to people's eating habits [3]. In the Czech Republic, pig breeding has a long tradition and consumption of pork has long been maintained at above $40 \mathrm{~kg} /$ person/year. Pork meat consumption has been an important feature of local culture [4].

Development and utilization of local pig breeds and providing information about them is very important for the protection of local resources and contributes significantly to the preservation of national culture heritage. The Prestice Black-Pied pig is an original Czech breed, kept as a closed population within the National Program for the Conservation and Utilization of Genetic Resources since 1992. This breed is kept in its purebred form and is not used for hybridization. It is characterized by good resistance, strong constitution, adaptability, longevity and good fertility. In comparison with modern breeds or hybrids, the Prestice Black-Pied pig has been characterized as having lower growth rate, lower lean meat content and higher fat percentage, similar to other local pig breeds such as Złotnicka Spotted or Cinta Senese [4-7].

However, there are only a few studies comparing the local Prestice Black-Pied breed with a productive multi-breed hybrid in terms of mortality, growth ability, carcass value as well as meat quality parameters. Previous experiments $[3,5]$ have mainly evaluated the effects of housing or slaughter weight on growth and meat quality in this breed. The aim of this study was to compare barrows and gilts of two contrasting genotypes (a native breed and a commercial hybrid) in terms of selected parameters of growth performance, carcass value and meat quality.

\section{Materials and Methods}

The experimental observations for this study took place from January to June 2020 in operational conditions of one productive farm in the Czech Republic in accordance with EU directives [8].

\subsection{Animals and Housing}

The study was carried out on a total of 39 pigs (19 barrows and 20 gilts) of the indigenous Prestice Black-Pied breed (PB) (Figure 1) and 37 pigs (17 barrows and 20 gilts) of the three-breed commercial hybrid of Large White $\times$ Landrace $\times$ Large White $_{\text {sireline }}$ (CH) (Figure 2).

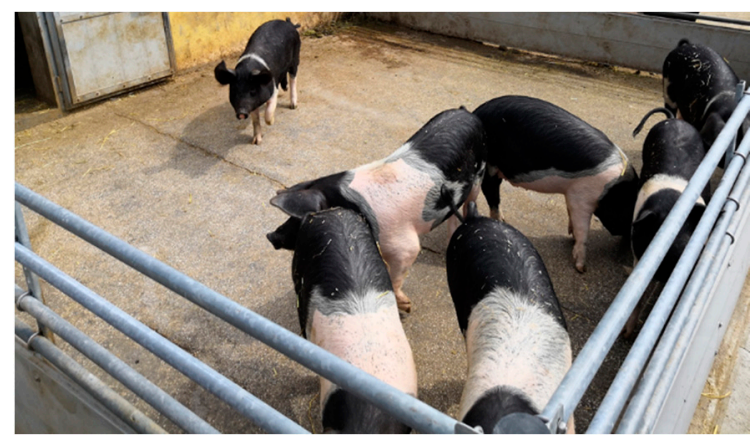

Figure 1. Prestice Black-Pied pigs.

The experiment was initiated after weaning of the piglets at an average age of 27 days. In the first phase of the experiment (Day 28-79, 52 days), the pigs were kept in two pens, divided by genotypes. The duration of this phase was equal for both genotypes. In the second phase of fattening, from Day 80 to the end of fattening, the pigs were kept in 4 pens, divided by genotype and sex. The duration of the second phase differed for each group according to the time that pigs reached the average slaughter weight of $95 \pm 6 \mathrm{~kg}$, i.e., at the age of 78 days for the $\mathrm{CH}$ group and 115 days for the $\mathrm{PB}$ group.

Both the groups were kept in identical conditions. During both stages of pre-fattening and fattening, the pigs were stabled in a closed stable on deep bedding. Straw was added 
two times per week and removed after removal of the animals. The floor space was $2 \mathrm{~m}^{2}$ per one pig.

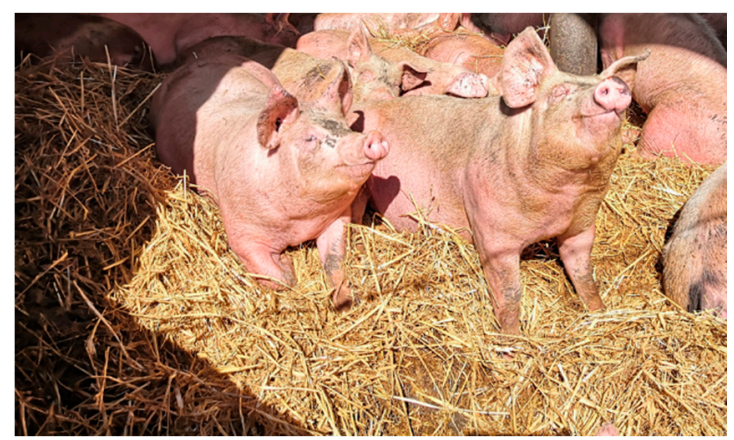

Figure 2. Commercial hybrids.

\subsection{Feeding and Composition of the Feed}

Both water and diet for pigs were available ad libitum. The diet in liquid form was fed in troughs equipped with sensors that controlled replenishment. The composition of the diet is shown in Table 1.

Table 1. Ingredients and nutrient composition of the diets.

\begin{tabular}{cccc}
\hline Ingredients (\%) & A1 & A2 & A3 \\
\hline Wheat & 36 & 42 & 46 \\
Barley & 25 & 30 & 32 \\
Soybean meal, extracted & 22 & 20 & 12 \\
Corn & 13 & 5 & 7 \\
Salt & 0.4 & 0.4 & 0.4 \\
Monocalcium phosphate & 0.5 & 0.5 & 0.5 \\
Magnesium oxide & 0.1 & 0.1 & 0.1 \\
Amino acids and vitamins & 3 & 2 & 2 \\
Nutrients (\%) & & & 88.4 \\
Dry matter & 88.2 & 88.9 & 1.7 \\
Fat & 5.4 & 2.4 & 14.3 \\
N-substances & 17 & 16.1 & 4.3 \\
Ash & 4.9 & 4.5 & 12.8 \\
ME (MJ/kg) & 13.0 & 12.9 & \\
\hline
\end{tabular}

A1: diet fed to pigs with average live weight to $35 \mathrm{~kg}$. A2: diet fed to pigs with average live weight to $60 \mathrm{~kg}$. A3: diet fed to pigs with average live weight to $100 \mathrm{~kg}$. ${ }^{1} 1 \mathrm{~kg}$ of vitamin-mineral premix provided: vitamin A, 667,000 IU; vitamin D3, 110,000 IU; vitamin E, $2800 \mathrm{IU}$; vitamin K3, $130 \mathrm{mg}$; vitamin B1, $140 \mathrm{mg}$; vitamin B2, $470 \mathrm{mg}$; vitamin B6, $195 \mathrm{mg}$; vitamin B12, $280 \mu \mathrm{g}$; niacinamide, $1445 \mathrm{mg}$; Ca pantothenate, $1000 \mathrm{mg}$; biotin, $5700 \mu$ g; choline $\mathrm{Cl}, 111,170 \mathrm{mg} ; \mathrm{CuSO}_{4} 5 \mathrm{H}_{2} \mathrm{O}, 1.100 \mathrm{mg}$; $\mathrm{FeSO}_{4} . \mathrm{H}_{2} \mathrm{O}, \mathrm{KI}, 84 \mathrm{mg}$; $\mathrm{MnO}, 3.340 \mathrm{mg}$; $\mathrm{ZnO}, 10,000 \mathrm{mg}$; $\mathrm{Na}_{2} \mathrm{O}_{3} \mathrm{Se}_{1}, 34 \mathrm{mg}$; lysine, $331 \mathrm{~g}$; methionine, $66 \mathrm{~g}$; threonine, $142 \mathrm{~g}$; tryptophan, $8 \mathrm{~g}$; endo-1,4-beta-xylanase (EC3.2.1.8), $122100 \mathrm{VU}$; endo-1,3 (4)-beta-glucanase (EC3.2.1.6), $166500 \mathrm{VU}$.

\subsection{Growth Performance}

The experiment was terminated when the pigs reached a live weight of $95 \pm 6 \mathrm{~kg}$. During the experimental observation, the animals were weighed individually three times, at weaning, at the age of 79 days and at the end of fattening, i.e., on the day of slaughter. At the end of the experiment, individual average daily gain was determined for the first and the second phase of the experiment. The average daily gain was calculated from the initial and final weights of individual animals in the observed time periods. Feed intake and conversion were determined from Day 80 to the slaughter, from group consumption of the feed mixture. These data were recalculated to find the feed intake and conversion per pig. 


\subsection{Procedures before Slaughter and Slaughter Measurements}

After termination of fattening, the pigs were transferred from the experimental facility to a slaughterhouse located within $40 \mathrm{~km}$. On the day of slaughter, the pigs were not fed, water was available. The animals were left to rest for about two hours before slaughtering. Then, they were slaughtered by electrical stunning (350 V, 4 A) and exsanguination. The carcasses were classified $45 \mathrm{~min}$ after the slaughter by a professional evaluator. Lean meat content was determined by the ZP method (Zwei-Punkt-Verfahren) [9]. The following equation was used for calculation:

$$
\text { Lean meat }(\%)=59.08991-0.433868 \times S+0.09792 \times M
$$

$S$ is the backfat thickness with skin measured at the point of the lowest layer above the middle of the musculus gluteus medius ( $\mathrm{mm}$ ).

$M$ is the muscle thickness between the cranial top of the musculus gluteus medius and the dorsal edge of the spinal canal ( $\mathrm{mm}$ ).

Another measurement of the carcasses (left side) was carried out $24 \mathrm{~h}$ after the slaughter at $4{ }^{\circ} \mathrm{C}$, according to the methodology of the Ministry of Agriculture of the Czech Republic [10]. The backfat thickness was measured at three points (in the middle of the second thoracic vertebra, at the last thoracic vertebra, and at the first sacral vertebra), and the arithmetic mean was calculated from these measurements. Of the main meat parts of the carcasses, ham with bones was weighed and its percentage was expressed. Subsequently, samples (500 g) of musculus longissimus lumborum et thoracis (MLLT) were collected between the second and the third last rib and transported in a portable fridge to the laboratory for further analysis.

\subsection{Physical and Chemical Analysis}

The muscle $\mathrm{pH}$ was measured $45 \mathrm{~min}$ and $24 \mathrm{~h}$ after the slaughter, using the InoLab pH 730 set (WTW, Weilheim, Germany) equipped with the SenTix Sp probe. The Minolta spectrophotometer (CM-2600d, Konica Minolta, Osaka, Japan) was used for measurement of the lightness $\left(\mathrm{L}^{*}\right)$, red-greenness $\left(\mathrm{a}^{*}\right)$ and yellow-blueness $\left(\mathrm{b}^{*}\right)$ parameters. $\mathrm{L}^{*}$ expresses lightness in the range from 100 (white) to 0 (black). Positive values of $a^{*}$ and $b^{*}$ determine color in the red and yellow spectra, while negative values determine color in the green and blue spectra. To ensure standardized measurement conditions, the measuring slit was set to $8 \mathrm{~mm}$, daylight light source-D65, $10^{\circ}$ Standard Observer angle and the specular component included (SCI) measurement mode were used. Drip loss value was calculated as weight loss of the fresh meat sample $(150 \mathrm{~g})$ placed in a plastic bag after storage for $24 \mathrm{~h}$ at $4{ }^{\circ} \mathrm{C}$. The drip loss value was expressed as a percentage of the initial weight according to Honikel [11]. Samples of the MLLT were homogenized and frozen for basic chemical analysis. Dry matter content was determined after drying in a hot-air dryer at $105^{\circ} \mathrm{C}$ for $4 \mathrm{~h}$ to a constant weight, when the samples were homogenized with use of the Grindomix GM 200 knife mill (Microtrac Retsch GmbH, Haan, Germany). Nitrogenous substances were determined using the Kjeltec Auto 1030 Analyzer (FOSS Tecator AB, Höganäs, Sweden), the values were subsequently converted to protein content in meat with a coefficient of 6.25. Intramuscular fat content in dry matter was then analyzed after extraction with petroleum ether on the Soxlet 1043 device (FOSS Tecator AB, Höganäs, Sweden) as described in ISO 1444 [12]. Cholesterol content was determined by lipid extraction by diethyl ether after saponification in accordance with ISO 3596 [13]. The muscle fiber diameter was measured in a meat sample of $1 \mathrm{~cm}^{3}$ put in formaldehyde (50 days). Prior to measurement, the sample was placed to nitric acid for 3-5 days in order to release the fibers. The diameter of the muscle fibers was measured under a microscope (Leica Microsystems, Wetzlar, Germany), and then, computer software version V3.5.0 (Leica, Heerbrugg, Switzerland) was used to evaluate the size of 250 fibers in one sample and the arithmetic mean was calculated from these measurements. Oxidative stability of the meat and fat was measured according to Piette and Raymond [14]. The basic principle of the method is determination of the content of thiobarbituric acid reactive species (TBARS). The main reactant is malondialdehyde 
(MDA) and the result is expressed as mg of malondialdehyde per $\mathrm{kg}$ of fresh meat. The measurement was performed at $4{ }^{\circ} \mathrm{C}$ on Day 1, Day 3 and Day 6 after slaughter.

\subsection{Statistical Analysis}

The two-way Analysis of variance was used for statistical analysis in STATISTICA 12.0 (StatSoft Inc., Tulsa, OK, USA) software. Testing of significant differences was carried out according to the following mathematical-statistical two-way analysis model:

$$
Y i j=\mu+d i+s j+(d s) i j+e i j
$$

where:

$Y i j=$ value of the trait

$\mu=$ overall mean

$d i=$ effect of genotype $(i=1,2)$

$s j=$ effect of $\operatorname{sex}(j=1,2)$

$(d s) i j=$ combined effect of genotype and sex

$e i j=$ random residual

When the analysis of variance showed significant differences between groups, the Tukey's HSD (Honestly Significant Difference) test was used. The data in the Tables are presented as the arithmetic mean and the standard error of the mean (SEM). One pig represented an experimental unit for weight gain, carcass characteristics and physical and chemical composition. Feed intake and feed conversion were measured per group, i.e., they provide descriptive information without statistical evaluation. The differences between the assessed groups were considered significant at $p<0.05$.

\section{Results}

\subsection{Performance Parameters in Pigs}

Results of the performance parameters are shown in Table 2 Most of them were affected by genotype and sex, however no interactions between those factors were confirmed. For the parameter of live weight $(\mathrm{LW})$, the $\mathrm{CH}$ pigs weighed $6.20 \mathrm{~kg}(p<0.001)$ more at the age of 79 days and $3.87 \mathrm{~kg}$ more at the time of slaughter $(p<0.01)$ than the PB pigs. A similar trend was observed for the average daily gains (ADG). The ADG was higher by $114.21 \mathrm{~g}$ $(p<0.001)$ between the 28th and 79th day, and by $254.91 \mathrm{~g}(p<0.001)$ between the 80th day and slaughter in the $\mathrm{CH}$ pigs, when compared to the $\mathrm{PB}$ pigs. With regard to the effect of sex, the LW was higher in barrows than in gilts, both at the age of 79 days (by $2.54 \mathrm{~kg}$; $p<0.01$ ) and at the time of slaughter (by $7.86 \mathrm{~kg} ; p<0.001$ ). Evaluation of the ADG showed similar results for the interval between the 28th and 79th day (by $41.66 \mathrm{~g} ; p<0.05$ ) as well as for the interval between the 80th day and the slaughter (45.75 g; $p<0.001)$.

\subsection{Carcass Characteristics in Pigs}

Carcass characteristics are presented in Table 3 . All the evaluated parameters were affected by genotype. Carcass weight was higher by $2.42 \mathrm{~kg}(p<0.05)$, left side weight was higher by $1.31 \mathrm{~kg}(p<0.05)$, weight and percentage of ham was higher by $1.78 \mathrm{~kg}$ and $4.04 \%$, respectively $(p<0.001)$, and lean meat content was higher by $4.40 \%(p<0.001)$ in the $\mathrm{CH}$ pigs. Backfat thickness was lower by $14.40 \mathrm{~mm}(p<0.001)$ in the $\mathrm{CH}$ pigs. Regarding the effect of sex, the carcass weight was higher by $5.90 \mathrm{~kg}(p<0.001)$, the left side weight was higher by $2.93 \mathrm{~kg}(p<0.001)$ and the backfat thickness was higher by $3.31 \mathrm{~mm}$ in barrows, while the lean meat content was higher in gilts by $2.67 \%(p<0.001)$. Interactions between genotype and sex were confirmed for the lean meat content $(p<0.05)$ and the backfat thickness $(p<0.01)$. The highest lean meat content and the lowest backfat thickness was found in the $\mathrm{CH}$ gilts, while in the PB barrows it was contrariwise. 
Table 2. Performance parameters in pigs depending on genotype and sex.

\begin{tabular}{|c|c|c|c|c|c|c|c|c|}
\hline \multirow{4}{*}{$\begin{array}{c}\text { Item } \\
\text { Sex (S) }\end{array}$} & \multicolumn{4}{|c|}{ Genotype (G) } & & \multirow{2}{*}{\multicolumn{3}{|c|}{$\begin{array}{c}\text { Significance } \\
p \text {-Value }\end{array}$}} \\
\hline & \multicolumn{2}{|c|}{ PB } & \multicolumn{2}{|c|}{$\mathrm{CH}$} & \multirow{3}{*}{ SEM } & & & \\
\hline & Barrows & Gilts & Barrows & Gilts & & \multirow{2}{*}{ G } & \multirow{2}{*}{$\mathbf{S}$} & \multirow{2}{*}{$G \times S$} \\
\hline & $n=19$ & $n=20$ & $n=17$ & $n=20$ & & & & \\
\hline Age at slaughter & 194 & 194 & 157 & 157 & - & - & - & - \\
\hline $\begin{array}{c}\text { Live weight }(\mathrm{kg}) \\
\text { at the age of } 27 \text { days } \\
\text { at the age of } 79 \text { days } \\
\text { at slaughter }\end{array}$ & $\begin{array}{c}6.03 \\
26.34 \\
99.04\end{array}$ & $\begin{array}{c}6.34 \\
23.10 \\
88.88\end{array}$ & $\begin{array}{l}7.08 \\
32.07 \\
100.7\end{array}$ & $\begin{array}{c}5.98 \\
29.90 \\
95.09\end{array}$ & $\begin{array}{l}0.18 \\
0.62 \\
0.87\end{array}$ & $\begin{array}{c}0.336 \\
<0.001 \\
0.006\end{array}$ & $\begin{array}{c}0.263 \\
0.008 \\
<0.001\end{array}$ & $\begin{array}{l}0.050 \\
0.581 \\
0.115\end{array}$ \\
\hline $\begin{array}{l}\text { Average daily gain }(\mathrm{g}) \\
\text { 28th-79th day } \\
\text { 80th day-slaughter } \\
\text { AFI 80th day-slaughter }(\mathrm{kg} / \text { day }) \\
\text { FCR 80th day-slaughter }(\mathrm{kg} / \mathrm{kg})\end{array}$ & $\begin{array}{c}390.6 \\
632.2 \\
2.51 \\
3.89\end{array}$ & $\begin{array}{c}322.4 \\
572.0 \\
2.26 \\
3.87\end{array}$ & $\begin{array}{c}480.7 \\
880.6 \\
2.48 \\
2.83\end{array}$ & $\begin{array}{c}460.6 \\
835.5 \\
2.30 \\
2.74\end{array}$ & $\begin{array}{c}11.44 \\
16.36 \\
- \\
-\end{array}$ & $\begin{array}{c}<0.001 \\
<0.001 \\
- \\
-\end{array}$ & $\begin{array}{c}0.018 \\
<0.001 \\
- \\
-\end{array}$ & $\begin{array}{c}0.190 \\
0.569 \\
- \\
-\end{array}$ \\
\hline
\end{tabular}

PB: Prestice Black-Pied pig; CH: commercial hybrid; AFI: average feed intake; FCR: feed conversion ratio; $n$ : number of pigs in grup; SEM: standard error of the mean.

Table 3. Carcass characteristics depending on genotype and sex.

\begin{tabular}{|c|c|c|c|c|c|c|c|c|}
\hline \multirow{2}{*}{ Item } & \multicolumn{4}{|c|}{ Genotype (G) } & & \multirow{2}{*}{\multicolumn{3}{|c|}{$\begin{array}{c}\text { Significance } \\
p \text {-Value }\end{array}$}} \\
\hline & \multicolumn{2}{|c|}{ PB } & \multicolumn{2}{|c|}{$\mathbf{C H}$} & \multirow{3}{*}{ SEM } & & & \\
\hline \multirow{2}{*}{ Sex (S) } & Barrows & Gilts & Barrows & Gilts & & $C$ & $\mathbf{S}$ & $G \times \mathbf{S}$ \\
\hline & $n=19$ & $n=20$ & $n=17$ & $n=20$ & & G & 3 & $0 \times 3$ \\
\hline Carcass weight (kg) & 77.15 & 69.17 & 77.54 & 73.72 & 0.67 & 0.028 & $<0.001$ & 0.063 \\
\hline Left carcass side $(\mathrm{kg})$ & 38.51 & 34.52 & 38.80 & 36.90 & 0.33 & 0.018 & $<0.001$ & 0.061 \\
\hline Ham (kg) & 7.17 & 6.61 & 8.72 & 8.61 & 0.15 & $<0.001$ & 0.113 & 0.289 \\
\hline Ham percentage $(\%)$ & 18.55 & 19.17 & 22.45 & 23.31 & 0.31 & $<0.001$ & 0.061 & 0.910 \\
\hline Lean meat content $(\%)$ & $52.74^{\mathrm{c}}$ & $56.35^{b}$ & $58.23^{a}$ & $59.64^{\mathrm{a}}$ & 0.37 & $<0.001$ & $<0.001$ & 0.016 \\
\hline Backfat thickness (mm) & $32.11^{\mathrm{a}}$ & $26.85^{b}$ & $15.25^{c}$ & $14.81^{\mathrm{c}}$ & 0.95 & $<0.001$ & $<0.001$ & 0.006 \\
\hline
\end{tabular}

PB: Prestice Black-Pied pig; CH: commercial hybrid; ${ }^{\mathrm{a}-\mathrm{c}}$ : Means within a row with different superscript letters differ at $p<0.05 ; n$ : number of pigs in grup; SEM: standard error of the mean.

\subsection{Physical and Chemical Characteristics of Musculus Longissimus Lumborum et Thoracis}

Table 4 presents the physical and chemical traits of the MLLT. Most of the observed parameters were affected by genotype. The PB pigs showed higher $\mathrm{pH}_{45}(p<0.01)$ and $\mathrm{pH}_{24}(p<0.001)$ values. Meat color was also influenced by genotype. The $\mathrm{L}^{*}$ value was lower $(p<0.001)$ in the PB pigs, as well as the $\mathrm{b}^{*}$ value $(p<0.01)$. Meat of the PB pigs was also characterized by lower drip loss value (by $0.63 \% ; p<0.05$ ), lower dry matter content (by $1.82 \% ; p<0.001$ ) and protein content (by $2.48 \%, p<0.001$ ) but with higher intramuscular fat content (by $0.68 \%, p<0.001$ ). Cholesterol content and size of muscle fibers was not influenced by genotype. Fat stability, expressed as the amount of TBARS was slightly more favorable in the PB pigs, by $0.04 \mathrm{mg}$ of MDA $(p<0.01)$ on Day 3 of storage and by $0.03 \mathrm{mg}$ of MDA $(p<0.05)$ on Day 6 . A significant effect of sex was observed for meat color, dry matter content and cholesterol content. The gilts showed lower $(p<0.05) \mathrm{L}^{*}$ and $b^{*}$ values, and also lower dry matter content (by $0.97 \%, p<0.01$ ) and lower cholesterol content (by $5.83 \mathrm{mg}$ ) than the barrows. Interactions between genotype and sex were found for the $\mathrm{pH}_{24}(p<0.001)$ with the highest value recorded in the PB barrows and the lowest in the $\mathrm{CH}$ barrows. Another interaction was confirmed for dry matter content $(p<0.05)$ with the lowest content found in the PB gilts and the highest content in the $\mathrm{CH}$ barrows. 
Table 4. Physical and chemical characteristics of musculus longissimus lumborum et thoracis (MLLT) muscle depending on genotype and sex.

\begin{tabular}{|c|c|c|c|c|c|c|c|c|}
\hline \multirow{2}{*}{ Item } & \multicolumn{4}{|c|}{ Genotype (G) } & \multicolumn{4}{|c|}{ Significance } \\
\hline & \multicolumn{2}{|c|}{ PB } & \multicolumn{2}{|c|}{$\mathrm{CH}$} & \multirow{3}{*}{ SEM } & \multicolumn{3}{|c|}{$p$-Value } \\
\hline \multirow{2}{*}{ Sex (S) } & Barrows & Gilts & Barrows & Gilts & & $C$ & $c$ & $C \times \mathbf{S}$ \\
\hline & $n=19$ & $n=20$ & $n=17$ & $n=20$ & & $\mathbf{G}$ & 3 & S \\
\hline $\mathrm{pH}_{45}$ & 6.23 & 6.35 & 6.08 & 6.16 & 0.03 & 0.006 & 0.110 & 0.764 \\
\hline $\mathrm{pH}_{24}$ & $5.68^{a}$ & $5.63^{a, b}$ & $5.51^{b}$ & $5.64^{\mathrm{a}, \mathrm{b}}$ & 0.01 & $<0.001$ & 0.091 & $<0.001$ \\
\hline \multicolumn{9}{|l|}{ Meat color } \\
\hline $\mathrm{L}^{*}$ (lightness) & 51.45 & 49.64 & 55.45 & 53.97 & 0.47 & $<0.001$ & 0.039 & 0.878 \\
\hline $\mathrm{a}^{*}$ (redness) & 1.27 & 1.30 & 1.49 & 1.82 & 0.13 & 0.158 & 0.487 & 0.564 \\
\hline $\mathrm{b}^{*}$ (yellowness) & 11.01 & 10.24 & 11.70 & 11.25 & 0.16 & 0.007 & 0.047 & 0.592 \\
\hline Drip loss (\%) & 2.95 & 2.94 & 3.77 & 3.35 & 0.15 & 0.040 & 0.482 & 0.461 \\
\hline Dry matter $(\%)$ & $27.18^{\mathrm{A}}$ & $25.32^{\mathrm{B}}$ & $28.12^{\mathrm{A}}$ & $27.99 \mathrm{~A}$ & 0.21 & $<0.001$ & 0.003 & 0.016 \\
\hline Protein (\%) & 20.04 & 20.20 & 21.96 & 23.15 & 0.33 & $<0.001$ & 0.263 & 0.390 \\
\hline Intramuscular fat (\%) & 2.38 & 2.20 & 1.64 & 1.58 & 0.04 & $<0.001$ & 0.059 & 0.316 \\
\hline Cholesterol (mg/g) & 68.07 & 61.69 & 63.32 & 58.29 & 1.38 & 0.134 & 0.038 & 0.803 \\
\hline Muscle fiber diameter $(\mu \mathrm{m})$ & 66.58 & 66.25 & 69.78 & 68.90 & 0.96 & 0.137 & 0.754 & 0.888 \\
\hline \multicolumn{9}{|l|}{ TBARS (MDA mg/kg) } \\
\hline Day 1 & 0.13 & 0.15 & 0.16 & 0.17 & 0.01 & 0.065 & 0.373 & 0.577 \\
\hline Day 3 & 0.15 & 0.16 & 0.19 & 0.19 & 0.01 & 0.004 & 0.548 & 0.688 \\
\hline Day 6 & 0.17 & 0.19 & 0.21 & 0.22 & 0.01 & 0.010 & 0.266 & 0.442 \\
\hline
\end{tabular}

PB: Prestice Black-Pied pig; CH: commercial hybrid; TBARS (MDA): Thiobarbituric Acid Reactive Species (malondialdehyde); ${ }^{\text {a,b }}$ : Means within a row with different superscript letters differ at $p<0.05$; $\mathrm{A}, \mathrm{B}$ : Means within a row with different superscript letters differ at $p<0.01$; $n$ : number of pigs in group; SEM: standard error of the mean.

\section{Discussion}

\subsection{Performance Parameters in Pigs}

The results of this study show differences between the two genotypes in growth intensity and selected characteristics of the carcass and meat quality. The analysis of growth parameters in pigs did not show surprising results as two contrasting genotypes were compared (indigenous breed and hybrid), and it is well known that hybrid pigs reach higher growth intensity than indigenous breeds. This is not only due to intensive breeding, but also due to the heterosis effect based on the genetic variability of the original pig populations used for creating the hybrid [15-17]. Trends of low growth intensity in indigenous breeds have been documented by many studies $[15,18,19]$. The findings of this study are similar to the results of Szulc et al. [20], who recorded an ADG of $590 \mathrm{~g}$ (220 days, $119 \mathrm{~kg}$ ) in purebred Złotnicka Spotted pigs and an ADG of $620 \mathrm{~g}$ (185 days, $114 \mathrm{~kg}$ ) in hybrids with the Duroc breed. Additionally, Maiorano et al. [21], who evaluated indigenous Casertana breed $(\mathrm{C})$ and a three-breed hybrid of Landrace $\times$ Italian Large White $\times$ Duroc $(\mathrm{H})$ during rearing lasting 240 days, and found ADG of $478 \mathrm{~g}(140 \mathrm{~kg})$ in the $\mathrm{C}$ pigs and $674 \mathrm{~g}(202 \mathrm{~kg})$ in the $\mathrm{H}$ pigs. It is evident that in comparison with commercial hybrids, the indigenous breeds have less favorable feed conversion ratios, which was also confirmed in this experiment and this corresponds to the findings of other studies [3,22].

Regarding the effect of sex, significant differences were proven in growth intensity between barrows and gilts, with higher intensity of growth found in barrows. This trend was visible in both the evaluated groups. Our findings are in accordance with other studies $[5,23]$ where a significantly higher growth intensity was found in barrows than in gilts. For example, following the same breeding principles and age of pigs at slaughter, Peinado et al. [23] reported a higher ADG in barrows than in gilts, by $113 \mathrm{~g}$. However, in a significant number of studies, the differences in growth intensity between sexes are not so pronounced, in fact, they are often negligible, which suggests that this characteristic can differ depending on various factors, such as breeding systems, feeding strategies as well as genetic effects [24-26]. 


\subsection{Carcass Characteristics in Pigs}

The effect of genotype was evident in all the evaluated carcass characteristics. Carcass weight is significantly related to the live weight of pigs at the time of slaughter. The results show that the carcass weight of the $\mathrm{CH}$ pigs was higher when compared to the $\mathrm{PB}$ pigs, therefore, the weight of the left carcass side and the weight or percentage of ham was higher in the hybrid pigs. These results are consistent with the study by Franco et al. [27], who evaluated the local Celta $(\mathrm{C})$ breed and a hybrid of Landrace $\times$ Italian Large White $\times$ Duroc $(\mathrm{H})$. With a slaughter weight of $168 \mathrm{~kg}$, they found a lower carcass weight in the C pigs $(133 \mathrm{~kg})$ than in the H pigs $(136.86 \mathrm{~kg})$ and a lower weight of ham $(20.99 \mathrm{~kg})$ in the C pigs vs. 22.18 in the H pigs. Nevertheless, some studies that have focused on carcass composition or percentage of ham in specific, suggest that there are no important differences between indigenous breeds and modern breeds or hybrids [21]. Even Szulc et al. [20] proved higher percentage of ham in the Złotnicka Spotted breed than in the Złotnicka Spotted $\times$ Duroc hybrid $(10.21 \mathrm{~kg}$ vs. $9.79 \mathrm{~kg})$ with carcass weight of $91 \mathrm{~kg}$. These results indicate that there are significant differences among individual local breeds and the composition of the carcass can be affected by the environment in which the breeds were reared [28]. Besides, a great number of previous studies differ significantly in the slaughter weight of the evaluated groups of pigs [21,29]. For an objective evaluation of pig carcasses or for launching on the market, the lean meat content must be determined. Native breeds are used for specific meat characteristics; thus, they do not achieve lean meat content at the same level as meat breeds. Also, backfat thickness is much higher in traditional breeds than in modern breeds. This trend is evident in most studies $[5,7,21,29]$. As in our study, Szulc et al. [20] also recorded a lean meat content of $41.83 \%$ and $34.96 \mathrm{~mm}$ for the backfat thickness in the Złotnicka Spotted $(119.20 \mathrm{~kg})$ vs. a lean meat content of $45.89 \%$ and a backfat thickness of $29.67 \mathrm{~mm}$ in the hybrid pigs $(114.10 \mathrm{~kg}$ ). Similar tendencies were observed in the indigenous Japanese breed of Agu (117.7 kg) and a hybrid of Large White $\times$ Landrace $\times$ Duroc $(112.3 \mathrm{~kg})$, the native breed was characterized by a backfat thickness of $41.4 \mathrm{~mm}$ and $24.7 \mathrm{~cm}^{2}$ of the area of longissimus dorsi above the last rib, the values in the hybrid pigs were $20.6 \mathrm{~mm}$ and $44.10 \mathrm{~cm}^{2}$ [30].

The effect of sex was confirmed for the carcass weight and the weight of the left carcass side, as well as for the lean meat content and the backfat thickness. Among other things, our study shows clearer differences between the animals by sex in the evaluated parameters in the $\mathrm{PB}$ population than in the $\mathrm{CH}$ pigs, which suggests more pronounced manifestations of sexual dimorphism in native breeds [31]. It could also relate to the higher pressure on uniformity, corresponding to breeding aims in commercial pig populations [2]. Franco et al. [30] also documented a lower live weight or carcass weight in gilts than in barrows; they recorded a difference of $3.17 \mathrm{~kg}$ in favor of barrows. Kim et al. [32] evaluated hybrids of Landrace $\times$ Yorkshire $\times$ Woori with similar findings, that is, the carcass weight was higher in castrates than in gilts $(97.37 \mathrm{vs.} 91.97 \mathrm{~kg})$ as well as the backfat thickness (31.23 vs. $36.31 \mathrm{~mm}$ ). Kernerová et al. [33] found $57.97 \%$ of the lean meat content in gilts versus $54.22 \%$ in barrows of the Large White $\times$ Landrace $\times$ Large White $_{\text {sireline }}$ hybrid $(116.32 \mathrm{~kg})$. Also, Kapelanski et al. [7], who evaluated the carcass traits in the native Złotnicka Spotted breed $(100 \mathrm{~kg})$, described differences between sexes. They recorded an average backfat thickness of $33.2 \mathrm{~mm}$ and a lean meat content of $43.53 \%$ in barrows, and $31.7 \mathrm{~mm}$ for the backfat and $45.63 \%$ for the lean meat in gilts.

Significant interactions between genotype and sex were confirmed for the lean meat content and the backfat thickness. The $\mathrm{CH}$ gilts showed the highest lean meat content and the lowest backfat thickness values at the same time. On the contrary, the lowest lean meat content and the highest backfat thickness were recorded for the PB barrows. This fact can be associated to feed consumption. Cassady et al. [17] demonstrated that pigs with higher feed intake show tendencies to build more fat deposits, while the lean meat content is lower. According to Jiang et al. [19], this trend could be related to the degree of breeding, with higher fat content and lower lean meat content recorded in native populations, which is also evident in our study. 


\subsection{Physical and Chemical Characteristics of Musculus Longissimus Lumborum et Thoracis}

Values describing $\mathrm{pH}$ show that both evaluated pig populations have normal meat without defects. Meat of the PB pigs showed higher $\mathrm{pH}_{45,24}$ values, which confirms higher stability of the meat. Also, the drip loss values were lower, which is in accordance with the statement that a lower drip loss is related to higher $\mathrm{pH}$ values [30]. Muhlisin et al. [34] found more stable $\mathrm{pH}_{24}$ (5.62 vs. 5.56) and a lower drip loss in Korean Native Black pigs than in their hybrids with Duroc. This trend was also observed in the Japanese breed of Agu and the Large White $\times$ Landrace $\times$ Duroc hybrid $\left(\mathrm{pH}_{48} 5.61\right.$ vs. 5.53; drip loss $2.03 \%$ vs. $2.75 \%$ ) [30]. However, in some studies, differences between contrasting genotypes were not found $[27,35]$. Meat color has been described as one of the most important quality parameters, determining the preferences of consumers who often ask for darker, redder meat [36]. Differences in the $a^{*}$ spectra between the groups were not significant, but the meat of the PB pigs was darker with lower yellow shades. This finding corresponds to the study of Kasprzyk et al. [37] who recorded the $L^{*}$ of 52.45; the $a^{*}$ of 3.19 and the $b^{*}$ of 9.65 in the Pulawaska breed and the $L^{*}$ of 53.42; the $a^{*}$ of 4.46 and the $\mathrm{b}^{*}$ of 10.55 in the Polish Landrace. Similar findings were presented by Alfonso et al. [38] in the Basque pig in comparison with the Large White breed, but with redder shade in the Basque breed $\left(L^{*} 43.4 ; a^{*} 6.0 ; b^{*} 8.0\right.$ vs. $\left.L^{*} 48.0 ; a^{*} 4.3 ; b^{*} 8.9\right)$. However, studies on the effect of breed or hybrid combinations on meat color are often questionable. Some authors have described insignificant effects of breed on meat color, and eventually the results were opposite $[28,29,34]$, which implies that further research is still needed. The chemical analysis of MLLT showed significant differences between the observed groups for some characteristics. It is evident, that the $\mathrm{CH}$ pigs are characterized with a higher dry matter content and protein content, which may be associated to higher drip loss values and lower intramuscular fat content when compared to the PB pigs. Even Zhang et al. [37] recorded a lower content of dry matter $(25.27 \%)$, nitrogenous substances $(22.88 \mathrm{~g})$ and a higher content of intramuscular fat $(4.8 \%)$ in the indigenous Jiaxing Black breed compared toa higher content of dry matter $(27.17 \%)$ and nitrogenous substances $(24.06 \mathrm{~g})$ and a lower intramuscular fat content $(3.72 \%)$ in the Duroc $\times$ Landrace $\times$ Jiaxing Black hybrid. Slightly different results were presented by Stanišić et al. [39], who observed a lower protein content $(22.68 \%$ vs. $24.29 \%)$, a lower intramuscular fat content (5.42\% vs. $1.85 \%)$, but a higher dry matter content $(29.21 \%$ vs. $27.57 \%)$ in meat of the Mangalitsa vs. Swedish Landrace. Other studies also often provide conflicting results of dry matter and protein contents in meat, but all studies are consistent in their statements that the meat of native breeds contains significantly more intramuscular fat than the meat of commercial breeds or hybrids $[20,21,28,32,40]$. Our experiment did not prove a relation between genotype and the cholesterol content. However, for example, Parunović et al. [41] found higher cholesterol content (by 15.8\%) in the meat of Mangalitsa than in the meat of Swedish Landrace. Our observations did not prove an effect of genotype on muscle fiber diameter, however, it is evident that muscle fibers in the meat of $\mathrm{CH}$ pigs are stronger, which is related to a higher lean meat content [42]. In the present study, meat oxidation was affected by genotype on Day 3 and Day 6 after the slaughter. In a previous experiment, when the PB pigs were slaughtered with a higher slaughter weight of 111.63 at the age of 204 days, a higher concentration of MDA was observed only on the first day in the commercial pigs (0.06 vs. $0.04 \mathrm{mg})$, which suggests that slaughter weight can play a role in this respect [4]. Differences could be related to physical activity of animals, the native breeds are usually very active [22] and therefore, the MDA level in meat of the PB pigs could be lower than in the $\mathrm{CH}$ pigs. This is supported by the statement of Allesio et al. [43] that increased physical activity correlates with the more effective control mechanisms of oxidative metabolism in muscles and production of reactive species. Nevertheless, further research needs to be done to clarify this finding and provide more knowledge on meat oxidative stability among pig breeding combinations.

Effects of sex were observed for meat color, dry matter content and cholesterol content. The effect of sex on meat color has been confirmed in many studies, meat of barrows is 
lighter than meat of gilts, in general [27,34]. In accordance to our findings, meat of the Celta breed was described with higher values of $L^{*}(52.04)$ and $b^{*}(11.20)$ and a lower value of $a^{*}(8.23)$ in barrows compared to the $L^{*}(47.82), b^{*}(9.38)$ and $a^{*}(8.80)$ found in gilts [44]. Similar differences between sexes (barrows vs. gilts) were presented by Lertpatarakomol et al. [35] in Large White $\times$ Landrace $\times$ Duroc hybrids ( $L^{*} 53.16$ vs. 50.67; $a^{*} 3.29$ vs. $3.81 ; b^{*} 12.08$ vs. 16.67$)$. These differences could be due to differing proportions of muscle fibers between gilts and barrows. Picard et al. [45] state that gilts showed a higher proportion of IIb type muscle fibers and lower proportions of I and IIa types than barrows. In general, the IIb type fibers are lighter, while the types I and IIa are darker and redder. However, the effect of sex on meat color is questionable. Some researchers found no differences in the $L^{*}$ values between sexes and emphasized the effect of slaughter weight and breeding system [5,32,34]. Dry matter content was lower in gilts. Similar tendencies were presented by Franco et al. [27] and Muhlisin et al. [34], who found values in gilts were lower by approximately $1 \%$. Nevertheless, Kim et al. [32] did not confirm this relationship. Cholesterol content was higher in barrows than in gilts. Dorado et al. [46] also found a higher content of cholesterol in barrows of the Belgian White $\times$ Landrace by $7 \mathrm{mg} / 100 \mathrm{~g}$, and they attributed this finding to the intramuscular fat content. The authors note that the higher the fat content, the higher the content of cholesterol. This trend was also described by Thomas et al. [47], who recorded a higher cholesterol content in barrows than in gilts (61.08 $\mathrm{mg}$ vs. $58.15 \mathrm{mg}$; intramuscular fat content $3.53 \%$ vs. $3.17 \%$ ) of the Ghungroo $\times$ Hampshire $\times$ Duroc hybrid.

Interactions between sex and genotype were found for the $\mathrm{pH}_{24}$, with the highest value recorded in the PB barrows and the lowest in the $\mathrm{CH}$ barrows. Similar interactions were described by Muhlisin et al. [34] who compared Korean Native Black pigs and their hybrids with Duroc. Nevertheless, some studies $[27,37]$ revealed no interactions between sex and genotype. The present study also showed interaction for the dry matter content, with the highest value found in the $\mathrm{CH}$ barrows and the lowest in the PB gilts. This trend could be related to the drip loss values, since the pigs with lower drip loss values also showed lower dry matter content and vice versa [37,39]. However, the interaction effects on meat quality parameters are often uneven. Quality of meat is affected by both genotype and sex, as well as by their interaction, however, the effects of the interactions are limited and do not manifest equally in all pig populations.

\section{Conclusions}

The results of this study showed that the PB pigs did not reach the growth intensity of the three-breed commercial hybrid (Large White $\times$ Landrace $\times$ Large White $_{\text {sireline}}$ ) and also the carcass value parameters were worse. However, the benefits of the PB pigs are the parameters of meat quality. Meat of the PB pigs was characterized by more stable $\mathrm{pH}$. The meat was darker with lower values of drip loss and a higher intramuscular fat content, but not so high as to decrease the acceptance of the meat by consumers. The cholesterol content was not higher than in the $\mathrm{CH}$ pigs. A benefit of the PB pigs is higher meat stability in comparison with the $\mathrm{CH}$ pigs. Based on these results, it can be concluded that the PB pigs could be suitable for alternative breeding systems, where demands on growth parameters in pigs are not primary. The PB pigs are able to provide meat of good quality, which could satisfy the demands of consumers and provide an interesting alternative to meat from commercial pig herds.

Author Contributions: P.N. conceived, designed and performed the experiments; P.N. and E.V. analyzed the data; P.N., E.V. and M.R. contributed to the analysis tools; P.N. wrote the paper. All authors have read and agreed to the published version of the manuscript.

Funding: Supported by the project of the Ministry of Agriculture of the Czech Republic, Institutional support No. MZE-RO0718.

Institutional Review Board Statement: The experiment was approved by the Ethics Committee of Mendel University Brno, Czech Republic (accreditation no. 16252/2015-MZE-17214). 
Informed Consent Statement: Informed consent was obtained from all subjects involved in the study.

Data Availability Statement: The data presented in this study are available on request from the corresponding author.

Conflicts of Interest: The authors declare no conflict of interest.

\section{References}

1. Gan, M.; Shen, L.; Fan, Y.; Guo, Z.; Liu, B.; Chen, L.; Tang, G.; Jiang, Y.; Li, X.; Zhang, S.; et al. High altitude adaptability and meat quality in tibetan pigs: A reference for local pork processing and genetic improvement. Animals 2019, 9, 1080. [CrossRef]

2. Teixeira, A.; Rodrigues, A. Pork Meat Quality of Preto Alentejano and Commercial Largewhite Landrace Cross. J. Integr. Agric. 2013, 12, 1961-1971. [CrossRef]

3. Dostálová, A.; Svitáková, A.; Bureš, D.; Vališ, L.; Volek, Z. Effect of an Outdoor Access System on the Growth Performance, Carcass Characteristics, and Longissimus lumborum Muscle Meat Quality of the Prestice Black-Pied Pig Breed. Animals 2020, 10, 1244. [CrossRef]

4. Nevrkla, P.; Kapelanski, W.; Vaclavkova, E.; Hadas, Z.; Cebulska, A.; Horky, P. Meat quality and fatty acid profile of pork and backfat from an indigenous breed and a commercial hybrid of pigs. Ann. Anim. Sci. 2017, 17, 1215-1227. [CrossRef]

5. Matousek, V.; Kernerova, N.; Hysplerova, K.; Jirotkova, D.; Brzakova, M. Carcass traits and meat quality of Prestice Black-Pied Pig Breed. Asian Australas. J. Anim. Sci. 2016, 29, 1181-1187. [CrossRef] [PubMed]

6. Sirtori, F.; Crovetti, A.; Zilio, D.M.; Pugliese, C.; Acciaioli, A.; Campodoni, G.; Bozzi, R.; Franci, O. Effect of sire breed and rearing system on growth, carcass composition and meat traits of Cinta Senese crossbred pigs. Ital. J. Anim. Sci. 2011, 10. [CrossRef]

7. Kapelanski, W.; Buczynski, J.T.; Bocian, M. Slaughter value and meat quality in the Polish native Zlotnicka Spotted pig. Anim. Sci. Pap. Rep. 2006, 24, 7-13.

8. Council Directive 2008/120/EC of 18 December 2008 Laying Down Minimum Standards for the Protection of Pigs (Codified Version). Available online: https:/ / eur-lex.europa.eu/eli/dir/2008/120/oj (accessed on 24 November 2020).

9. Commission Decision of 27 December 2004 Authorizing Methods for Grading Pig Carcases in the Czech Republic (Notified by Number C(2004) 2566) (Only the Czech Text is Authentic) (2005/1/EC). Available online: https:/ / eur-lex.europa.eu/legalcontent/EN/TXT/?uri=CELEX\%3A02005D0001-20130701 (accessed on 24 November 2020).

10. Methodical Instructions for Performance Testing in Pigs; Czech and Moravian Pig Breeders Union: Prague, Czech Republic, 2002.

11. Honikel, K.O. Reference methods for the assessment of physical characteristics of meat. Meat Sci. 1998, 49, 447-457. [CrossRef]

12. ISO 1444. Meat and Meat Products-Determination of Free Fat Content; International Organization for Standardization: Geneva, Switzerland, 1996.

13. ISO 3596. Animal and Vegetable Fats and Oils-Determination of Unsaponifiable Matter. Method Using Diethyl Ether Extraction; International Organization for Standardization: Geneve, Switzerland, 2000.

14. Piette, G.; Raymond, M.P. A comparative evaluation of methods to determine rancidity in processed meat (in German). Fleischwirtschaft 1999, 7, 69-73.

15. Leenhouwers, J.L.; Merks, J.W.M. Suitability of traditional and conventional pig breeds in organic and low-input production systems in Europe: Survey results and a review of literature. Anim. Genet. Resour. Inf. 2013, 53, 169-184. [CrossRef]

16. Bereskin, B.; Shelby, C.E.; Cox, D.F. Some factors affecting pig survival. J. Anim. Sci. 1973, 36, 821-827. [CrossRef] [PubMed]

17. Cassady, J.P.; Young, L.D.; Leymaster, K.A. Heterosis and recombination effects on pig growth and carcass traits. J. Anim. Sci. 2002, 80, 2286-2302. [CrossRef]

18. Fortina, R.; Barbera, S.; Lussiana, C.; Mimosi, A.; Tassone, S.; Rossi, A.; Zanardi, E. Performances and meat quality of two Italian pig breeds fed diets for commercial hybrids. Meat Sci. 2005, 71, 713-718. [CrossRef] [PubMed]

19. Jiang, Y.; Zhu, L.; Li, X.; Si, T. Evaluation of the Chinese indigenous pig breed Dahe and crossbred Dawu for growth and carcass characteristics, organ weight, meat quality and intramuscular fatty acid and amino acid composition. Animal 2011, 5, 1485-1492. [CrossRef] [PubMed]

20. Szulc, K.; Skrzypczak, E.; Buczynski, J.T.; Stanislawski, D.; Jankowska-Makosa, A.; Knecht, D. Evaluation of fattening and slaughter performance and determination of meat quality in Zlotnicka Spotted pigs and their crosses with the Duroc breed. Czech J. Anim. Sci. 2012, 57, 95-107. [CrossRef]

21. Maiorano, G.; Gambacorta, M.; Tavaniello, S.; D'Andrea, M.; Stefanon, B.; Pilla, F. Growth, Carcass and Meat Quality of Casertana, Italian Large White and Duroc x (Landrace x Italian Large White) Pigs Reared Outdoors. Ital. J. Anim. Sci. 2013, 12, $426-431$. [CrossRef]

22. Václavková, E.; Bělková, J.; Lustyková, A.; Frydrychová, S.; Lipenský, J.; Rozkot, M.; Truněčková, J. Breeding of Přeštice Black Pied pigs-Review. Res. Pig Breed. 2018, 12, 14-19.

23. Peinado, J.; Medel, P.; Fuentetaja, A.; Mateos, G.G. Influence of sex and castration of females on growth performance and carcass and meat quality of heavy pigs destined for the dry-cured industry. J. Anim. Sci. 2008, 86, 1410-1417. [CrossRef]

24. Sheikh, G.G.; Baghe, R.P.S.; Nayak, S.; Fatima, B.; Ganie, A.A. Effect of sex on growth performance, nutrient utilization and carcass characteristics in cross bred pigs. Indian J. Anim. Res. 2017, 51, 175-178. [CrossRef]

25. Aymerich, P.; Soldevila, C.; Bonet, J.; Farré, M.; Gasa, J.; Coma, J.; Solà-Oriol, D. Interrelationships between sex and dietary lysine on growth performance and carcass composition of finishing boars and gilts. Transl. Anim. Sci. 2020, 4, txaa129. [CrossRef] 
26. Li, W.; Li, R.; Wei, Y.; Meng, X.; Wang, B.; Zhang, Z.; Wu, W.; Liu, H. Effect of MSTN Mutation on Growth and Carcass Performance in Duroc $\times$ Meishan Hybrid Population. Animals 2020, 10, 932. [CrossRef]

27. Franco, D.; Vazquez, J.A.; Lorenzo, J.M. Growth performance, carcass and meat quality of the Celta pig crossbred with Duroc and Landrance genotypes. Meat Sci. 2014, 96, 195-202. [CrossRef] [PubMed]

28. Debrecéni, O.; Lípová, P.; Bučko, O.; Cebulska, A.; Kapelánski, W. Effect of pig genotypes from Slovak and Polish breeds on meat quality. Arch. Anim. Breed. 2018, 61, 99-107. [CrossRef]

29. Zhang, W.; Song, Q.Q.; Wu, F.; Zhang, J.Z.; Xu, M.S.; Li, H.H.; Han, Z.J.; Gao, H.X.; Xu, N.Y. Evaluation of the four breeds in synthetic line of Jiaxing Black Pigs and Berkshire for meat quality traits, carcass characteristics, and flavor substances. Anim. Sci. J. 2019, 90, 574-582. [CrossRef]

30. Touma, S.; Oyadomari, M. Comparison of growth performances, carcass characteristics, and meat qualities of Okinawan indigenous Agu pigs and crossbred pigs sired by Agu or Duroc boar. Anim. Sci. J. 2020, 91, e13362. [CrossRef]

31. McManus, C.; Paiva, S.R.; Silva, A.V.R.S.; Murata, L.S.; Louvandini, H.; Cubilllos, G.P.B.; Castro, G.C.; Martinez, R.A.; Dellacasa, M.S.L.; Perez, J.E. Phenotypic characterization of naturalized swine breeds in Brazil, Uruguay and Colombia. Braz. Arch. Biol. Technol. 2010, 53, 583-591. [CrossRef]

32. Kim, Y.M.; Choi, T.J.; Ho Cho, K.; Cho, E.S.; Lee, J.J.; Chung, H.J.; Baek, S.Y.; Jeong, Y.D. Effects of Sex and Breed on Meat Quality and Sensory Properties in Three-way Crossbred Pigs Sired by Duroc or by a Synthetic Breed Based on a Korean Native Breed. Korean J. Food Sci. Anim. Resour. 2018, 38, 544-553.

33. Kernerová, N.; Matoušek, V.; Vejčík, V.; Václavovský, J.; Eidepesová, L. Field tests of three final hybrids of pigs. Res. Pig Breed. 2007, 1, 36-39.

34. Muhlisin; Panjono; Lee, S.J.; Lee, J.K.; Lee, S.K. Effects of crossbreeding and gender on the carcass traits and meat quality of korean native black pig and duroc crossbred. Asian Australas. J. Anim. Sci. 2014, 27, 1019-1025. [CrossRef] [PubMed]

35. Lertpatarakomol, R.; Chaosap, C.; Chaweewan, K.; Sitthigripong, R.; Limsupavanich, R. Carcass characteristics and meat quality of purebred Pakchong 5 and crossbred pigs sired by Pakchong 5 or Duroc boar. Asian Australas. J. Anim Sci. 2019, 32, 585-591. [CrossRef] [PubMed]

36. Mancini, R.A.; Hunt, M.C. Current research in meat color. Meat Sci. 2005, 71, 100-121. [CrossRef] [PubMed]

37. Kasprzyk, A.; Tyra, M.; Babicz, M. Fatty acid profile of pork from a local and a commercial breed. AAB 2015, 58, 379. [CrossRef]

38. Alfonso, L.; Mourot, J.; Insausti, K.; Mendizabal, J.A.; Arana, A. Comparative description of growth, fat deposition, carcass and meat quality characteristics of Basque and Large White pigs. Anim. Res. 2005, 54, 33-42. [CrossRef]

39. Stanišić, N.; Parunović, N.; Stajić, S.; Petrović, M.; Radović, Č.; Živković, D.; Petričević, M. Differences in meat colour between free-range Swallow Belly Mangalitsa and commercially reared Swedish Landrace pigs during 6 days of vacuum storage. Arch. Anim. Breed. 2016, 59, 159-166. [CrossRef]

40. Imrich, I.; Mlyneková, E.; Mlynek, J.; Halo, M.; Kanka, T. Comparison of the Physico-Chemical Meat Quality of the Breeds Mangalitsa and Large White with Regard to the Slaughter Weight. Potravin. Slovak J. Food Sci. 2020, 14, 135-141. [CrossRef]

41. Petrović, M.; Radović, Č.; Parunović, N.; Radojković, D.; Savić, R. Carcass properties, chemical content and fatty acid composition of the Musculus longissimus of different pig genotypes. S. Afr. J. Anim. Sci. 2013, 43, 123-136. [CrossRef]

42. Kasprzyk, A.; Bogucka, J. Meat quality of Pulawska breed pigs and image of longissimus lumborum muscle microstructure compared to commercial DanBred and Naima hybrids. Arch. Anim. Breed. 2020, 63, 293-301. [CrossRef]

43. Allesio, H.; Hagerman, A.; Fulkerson, B. Generation of reactive oxygen species after exhaustive aerobic and isometric exercise. Med. Sci. Sport Exer. 2000, 32, 1576-1581. [CrossRef] [PubMed]

44. Franco, D.; Lorenzo, J.M. Effect of gender (barrows vs. females) on carcass traits and meat quality of Celta pig reared outdoors. J. Sci. Food Agric. 2013, 93, 727-734. [CrossRef]

45. Picard, B.; Lefaucheur, L.; Berri, C.; Duclos, M.J. Muscle fiber ontogenesis in farm animal species. Reprod. Nutr. Dev. 2002, 42, 415-431. [CrossRef]

46. Dorado, M.; Martin Gomez, E.M.; Jimenez-Colmenero, F.; Masoud, T.A. Cholestrol and fat contents of Spanish commercial pork cuts. Meat Sci. 1999, 51, 321-323. [CrossRef]

47. Thomas, R.; Banik, S.; Mohan, N.H.; Sarma, D.K. Carcass and meat quality of triple cross (Ghungroo $\times$ Hampshire $\times$ Duroc) fattener pigs. Int. Food Res. J. 2017, 24, 153-158. 